\title{
纳木错水温变化及热力学分层特征初步研究
}

\author{
黄 磊 ${ }^{1,2}$, 王君波 ${ }^{1}$, 朱立平 ${ }^{1}$, 鞠建廷 ${ }^{1}$, 汪 勇 $^{1}$,马庆峰 ${ }^{1}$ \\ (1:中国科学院青藏高原研究所,青藏高原环境变化与地表过程重点实验室,北京 100101) \\ (2:中国科学院大学,北京 100049)
}

\begin{abstract}
摘 要: 水温变化是湖泊的重要物理特性,对湖泊的水质特征、湖水能量循环、水生生态系统研究具有重要意义. 基于不 同季节的实地观测资料,分析青藏高原高海拔、深水大湖纳木错的水温变化特征及季节差异,并着重分析湖水热力学分 层的季节变化. 结果显示纳木错中部、东部两个湖盆冬季封冻,夏季存在稳定分层, 春、秋季混合, 是一个典型双季对流、 完全混合型湖泊. 但两个湖盆水温变化与热力学分层又有各自的特征, 东部浅湖盆湖水在春季升温快, 夏季分层与秋季 翻转均比中部湖盆早, 且秋季翻转时水温也比中部湖盆高. 初步分析认为两个湖盆不同的湖盆形状及水深分布可能是造 成其热力学特征差异的主要原因.
\end{abstract}

关键词: 水温;热力学分层;季节变化;纳木错;青藏高原

\section{Water temperature and characteristics of thermal stratification in Nam Co, Tibet}

HUANG Lei ${ }^{1,2}$, WANG Junbo ${ }^{1}$, ZHU Liping ${ }^{1}$, JU Jianting ${ }^{1}$, WANG Yong ${ }^{1}$ \& MA Qingfeng ${ }^{1}$

(1: Key Laboratory of Tibetan Environment Changes and Land Surface Processes (TEL), Institute of Tibetan Plateau Research, Chinese Academy of Sciences, Beijing 100101, P. R. China)

(2: University of Chinese Academy of Sciences, Beijing 100049, P. R. China)

\begin{abstract}
Variation of water temperature is a critical physical property of a lake, which has great significance for other research, such as lake water quality, energy cycle, aquatic ecosystem. Illustrated by Nam Co, characteristics and seasonal differences of lake water temperature distribution were studied in a high altitude deep lake on the Tibetan Plateau, with in-situ monitoring data from different seasons. Then, seasonal variability of thermal stratification was emphatically analyzed. Results imply that in Nam Co, both the middle and eastern parts are frozen up in winter, completely mixed in spring and autumn, and steadily stratified in summer. Thus, Nam Co is a typical dimictic lake, and a holomictic lake at the same time. However, the two parts of Nam Co have unique characteristics in season variability of water temperature and thermal stratification respectively. In spring, temperature rises faster in the relatively shallow basin than that in the middle lake. Meanwhile, the date of summer stratification and autumn overturn is earlier in the shallow basin, in which water temperature is higher when circulated in autumn as well. By preliminary analysis, different topography under water and bathymetric distribution of the two basins probably contribute the most to the difference in the thermodynamic characteristic.
\end{abstract}

Keywords: Water temperature; thermal stratification; seasonal variability; Nam Co; Tibetan Plateau

中纬度地区的青藏高原是世界上面积最大、平均海拔最高的高原,受西风和亚洲夏季风交错影响. 它对 全球气候变化有敏感的响应, 同时对周边地区的大气环流、水文过程产生反馈, 从而影响十多亿人口的生产 生活. 因此,受到众多研究者的关注,其作为“地球第三极” 的概念已被广泛接受 ${ }^{[1]}$.

高原上湖泊众多,面积大于 $1.0 \mathrm{~km}^{2}$ 的湖泊就有 1091 个之多 ${ }^{[2]}$. 众多湖泊记录了丰富的、不同时空尺度 的环境变化信息, 是过去环境变化的研究窗口 ${ }^{[3]}$. 但是,湖泊沉积环境指标指示的环境意义复杂,带有混合

* 国家重点基础研究发展计划“973”项目 (2012CB956100)、国家自然科学基金项目(41071123) 和科技部基础性工 作专项 (2012FY111400) 联合资助. 2014-07-03 收稿;2014-12-18 收修改稿. 黄否 (1990 ), 男, 硕士研究生; E-mail:huanglei@ itpcas.ac.cn. 
信息. 准确理解指标代表的环境意义, 从而构建指标与环境要素之间的定量关系, 都依赖于湖泊现代过程研 究 $^{[4]}$. 目前, 高原湖泊现代过程研究还很薄弱, 基本以静态的基础调查为主. 由于大部分湖泊位于偏远地区, 较难开展长期连续的定位观测, 对于湖泊水质参数的连续变化特征研究尚未进行 ${ }^{[5-13]}$.

水温是湖泊水体的一项基本物理性质, 其空间分布与季节变化决定湖泊水体生物群落的结构以及相关 的生物生产力 ${ }^{[14-15]}$. 在中、高纬度地区湖泊中, 夏季水温在垂直方向上存在差异, 引起的热分层是湖泊年际 循环中最重要的物理事件 ${ }^{[16]}$. 通过热分层, 湖泊水体形成混合的湖上层、存在温度梯度的温跃层以及较少发 生扰动的湖下层. 热分层对湖泊内物质沉降、生态系统结构有重要影响. 利用沉积物捕获器对一年两次或单 次混合的塞营养湖泊敞水区进行的现代监测表明, 其沉降模式为单峰模式, 沉降速率最大值出现在湖泊混 合期 ${ }^{[14]}$. 最近在青海湖开展的类似工作则表明, 生物质通量变化主要受控于夏季温度的变化 ${ }^{[17]}, 2$ 个现生种 属介形虫 (意外湖花介和胖真星介) 的出现和丰度变化均受水温的直接影响, 其壳体碳、氧同位素也受到水 温的间接影响 ${ }^{[18]}$. 因此,认识湖泊水温变化和热分层对解译湖泊沉积物环境意义有重要作用.

此外, 在全球变暖背景下, 湖泊水温及热力学结构也发生着改变. 已有研究利用气候预测数据, 对未来 气温升高背景下北半球湖泊水温和热分层特征进行模拟分析. 这些研究认为湖水水温整体升高, 中高纬地 区湖泊的结冰期缩短, 分层提前开始而且夏季分层期延长, 湖上层水温也比湖下层水温增加得多, 从而导致 夏季分层加强,湖泊初级生产力和生物区系出现相应变化 ${ }^{[19-22]}$.

青藏高原是全球气候变化的敏感响应区. 在高原开展湖泊热力学的现代过程研究, 进而重建高原过去 环境变化以及认识湖泊生态系统变化就显得更有意义. 目前, 已有研究报道纳木错夏季存在水温分层现 象 ${ }^{[9]}$, 本文将基于 2011-2013 年野外调查获得的高分辨率、连续水体垂直温度变化数据, 进一步对纳木错 中心区域水温变化和热力学分层特征进行研究.

\section{1 研究区域}

纳木错 $\left(30^{\circ} 30^{\prime} \sim 30^{\circ} 55^{\prime} \mathrm{N}, 90^{\circ} 16^{\prime} \sim 91^{\circ} 03^{\prime} \mathrm{E}\right)$ 湖面海拔为 $4722 \mathrm{~m}^{[23-24]}$. 根据遥感图像解译结果, 2000 年 纳木错湖面面积为 $1979.79 \mathrm{~km}^{2}$. 整个湖泊流域的地理范围为 $29^{\circ} 56^{\prime} \sim 31^{\circ} 7^{\prime} \mathrm{N}, 89^{\circ} 21^{\prime} \sim 91^{\circ} 23^{\prime} \mathrm{E}$, 面积达 $10610 \mathrm{~km}^{2[24]}$. 纳木错流域处在冈底斯-念青唐古拉山的北部, 南岸念青唐古拉山平均海拔约为 $5500 \mathrm{~m}$, 发育 众多现代冰川. 2007 年整个流域内冰川面积为 $166.2 \mathrm{~km}^{2[25]}$.

纳木错流域处于高原亚寒带季风半干旱和半湿润气候地区的过渡带, 夏半年受南亚季风的影响, 温暖 湿润. 冬半年受西风环流的影响, 寒冷干燥. 根据中国科学院纳木错多圈层综合观测研究站 2005-2006 年的 自动气象站数据统计, 年平均气温 $-0.6^{\circ} \mathrm{C}$, 全年日平均气温高于 $0^{\circ} \mathrm{C}$ 的有 $173 \mathrm{~d} ; 7$ 月为最暖月, 12 月为最冷 月; 年平均风速为 $3.6 \mathrm{~m} / \mathrm{s}, 7$ 月平均风速为全年最低. 降水量为 $281.8 \mathrm{~mm}$, 多集中在 5-10 月份 ${ }^{[26]}$.

纳木错为封闭的微咸水湖, 1978 年实测表层水体的平均矿化度为 $1.78 \mathrm{~g} / \mathrm{L}$. 湖泊表层水体 $\mathrm{pH}$ 值在 $8.04 \sim 9.85$ 之间, 电导率差异较小, 约为 $1839 \mu \mathrm{S} / \mathrm{cm}$. 纳木错最大水深约为 $99 \mathrm{~m}$, 湖盆中部存在一个超过 $90 \mathrm{~m}$ 深的平坦盆地, 而东部湖盆的面积、水深均比中部湖盆小 ${ }^{[9]}$ (图 1). 湖水主要受地表径流、降水以及冰川 融水补给. 人湖河流主要分布在纳木错南侧以及西侧, 南侧河流受念青唐古拉山冰川补给, 分布密集且流程 短. 流域西侧的昂曲和侧曲为流域内主要补给河流 ${ }^{[23,27]}$. 流域内径流季节变化大, 丰水期为 5-10月, 尤其 集中在 7-8 月, 降水和冰雪消融是主要的补给方式 ${ }^{[12]}$.

\section{2 研究方法}

2011 年开始, 针对湖水理化性质在垂直方向上分布的季节变化, 在纳木错东部、中部两个湖盆分别选取 1 个 固定点, 开展连续野外调查取样工作. 其中, $\mathrm{T} 1$ 点 $\left(30^{\circ} 50^{\prime} 41^{\prime \prime} \mathrm{N}, 90^{\circ} 54^{\prime} 13^{\prime \prime} \mathrm{E}\right)$ 水深为 $57.0 \mathrm{~m}$; $\mathrm{T} 2$ 点 $\left(30^{\circ} 46^{\prime} 5^{\prime \prime} \mathrm{N}\right.$, $90^{\circ} 46^{\prime} 32^{\prime \prime} \mathrm{E}$ ) 水深为 $92.0 \mathrm{~m}$ (图 1). 利用美国哈希公司生产的 Hydrolab DS5 多参数水质仪在野外工作现场对 垂直剖面上的水质数据进行采集. 该仪器装有温度、 $\mathrm{pH}$ 、电导率等水质参数探头. 其中温度探头的有效工作 范围为 $-5 \sim 50^{\circ} \mathrm{C}$, 分辨率达到 $0.01^{\circ} \mathrm{C}$, 误差为 $\pm 0.1^{\circ} \mathrm{C}$. 同时, 仪器装有压力感应器, 通过仪器承受的水柱压 力计算仪器所处的水深, 测量范围为 $0 \sim 225 \mathrm{~m}$, 能精确到 $0.01 \mathrm{~m}$, 误差为 $\pm 0.05 \mathrm{~m}$. 在野外工作时, 将仪器垂 直放人湖水中, 平均约每 $0.5 \mathrm{~m}$ 采集 1 个数据, 并通过电缆与工作平台上的计算机相连, 实现数据的实时接 
收, 通过这种数据采集方式, 获得高度连续的垂直水质剖面数据. 根据纳木错实测数据, 本文将垂直剖面上 水温梯度大于 $0.1{ }^{\circ} \mathrm{C} / \mathrm{m}$ 的连续区域作为温跃层.

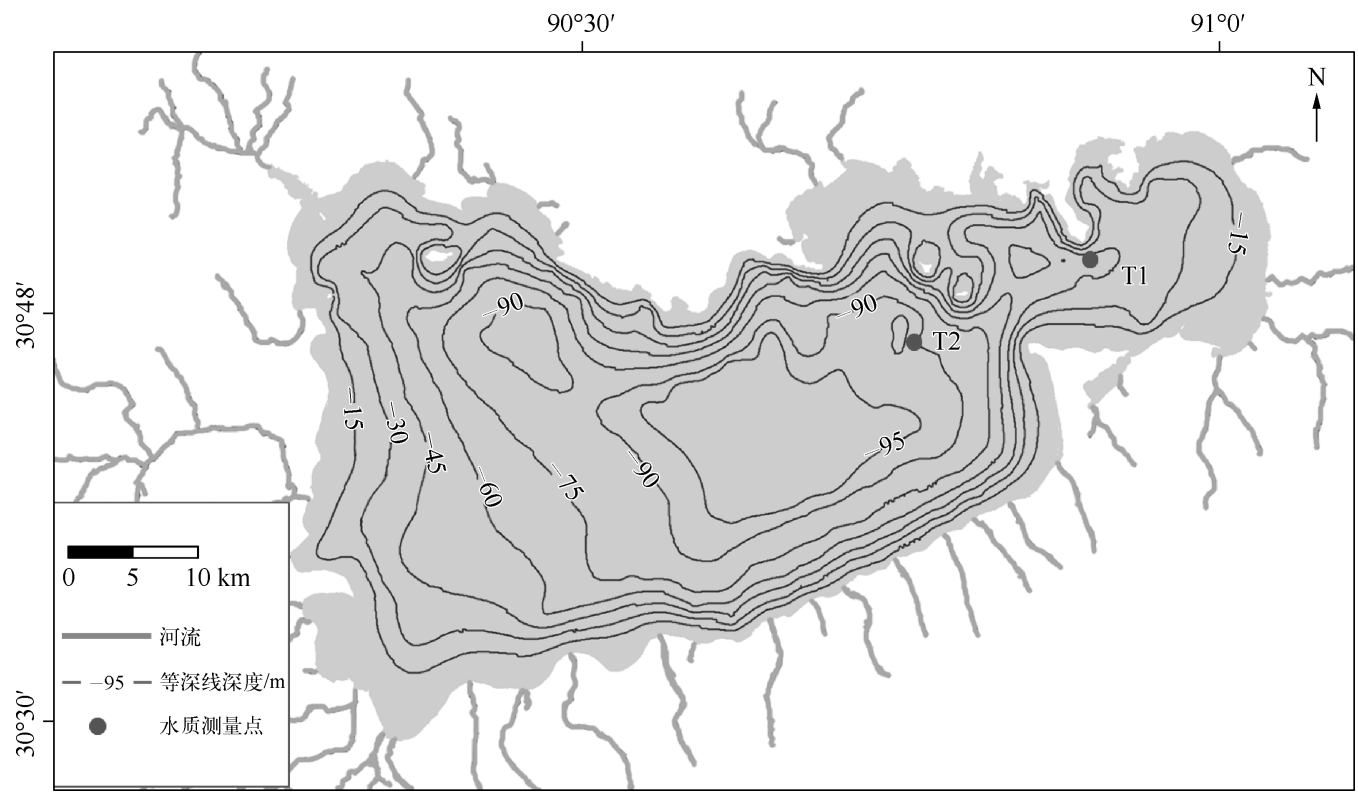

图 1 纳木错等深线图及水质测量点分布

Fig. 1 Isobath of Nam Co and water quality survey sites

\section{3 结果}

纳木错东部湖盆与中部湖盆的水下地形存在明显差异 (图 1), 从而对湖水能量循环产生重要影响. T1 点和 $\mathrm{T} 2$ 点分别处于这两个湖盆的敞水区, 二者离岸距离均在 $1 \mathrm{~km}$ 以上,且水深均接近所在湖盆最大水深.

纳木错在 2 月完全结冰, 5 月中旬完全解冻,封冻期约 $90 \mathrm{~d}^{[28]}$. 本文所使用数据都于纳木错春季解冻和 冬季结冰之间时间段采集. 由于不是在 1 年之内采集,而是将 3 年的观测数据综合起来(图 2), 因此,本文着 重就纳木错湖两个野外工作点垂直方向上的水温分布和分层过程的季节性变化来讨论湖泊混合类型, 而不 涉及某个周期内这些现象详细的时空变化过程.

\section{$3.1 \mathrm{~T} 1$ 点垂直剖面水温季节变化}

5 月份 $\mathrm{T} 1$ 点水温在垂直方向上没有出现剧烈变化. 2011 年 5 月 14 日,整个垂直剖面的湖水水温在 $2 \sim$ $3{ }^{\circ} \mathrm{C}$ 之间,上、下层温差小,这反映湖水上下层混合较好(图 2a).

6 月和 7 月 $\mathrm{T} 1$ 点水温开始出现分层. 在该段时间取得的 5 个水温剖面中,湖水底部水温都在 $3.6 \sim$ $4.8^{\circ} \mathrm{C}$ 之间波动. 而表层水温却有随着时间推移而明显增加的趋势, 从 6 月中旬的 $7.64^{\circ} \mathrm{C}$ 增加到 7 月中下旬 的 $13^{\circ} \mathrm{C} .2011$ 年 6 月 14 日,表层水温为 $7.64^{\circ} \mathrm{C}$, 底层为 $3.58^{\circ} \mathrm{C}$. 温跃层从 $22.8 \mathrm{~m}$ 左右水深处开始, 止于 $29 \mathrm{~m}$ (图 2a). 7 月中旬后, 显著的湖泊分层现象开始出现. 湖上层与湖下层水温随深度的变化微小, 但温跃 层上、下两端的温差开始变大. 在 2013 年 7 月 18 日的垂直剖面中, 湖上层比湖下层的水温高 $7.3^{\circ} \mathrm{C}$ 左右 (图 2c).

$8 、 9$ 月份, 温跃层进一步发展, 形状开始稳定, 温跃层的深度在不断增加, 但是其形状并没有明显改变. 湖上层混合较好,水温随深度的变化不大. 湖下层水温都维持在 $4^{\circ} \mathrm{C}$ 左右. 2013 年 8 月 14 日, 湖水表层水温 为 $11.4^{\circ} \mathrm{C}$, 湖上层水温基本一致. 温跃层从 $16.5 \mathrm{~m}$ 水深处开始, 到 $27 \mathrm{~m}$ 左右结束, 水温从 $11.4^{\circ} \mathrm{C}$ 左右降到 $5^{\circ} \mathrm{C}$ (图 2c). 2012 年 9 月 16 日, 温跃层深度增加到 $35 \mathrm{~m}$, 到 $46.3 \mathrm{~m}$ 结束. 整个湖上层的水温都保持在 $11.5 \sim$ $11.6^{\circ} \mathrm{C}$ 之间. 进人秋季后, 湖水发生混合 (图 $2 \mathrm{~b}$ ). 通过 2011 年 10 月 27 日湖水剖面可以看出, 在水温约 $8^{\circ} \mathrm{C}$ 
时,上、下层湖水翻转,整个剖面的湖水再次混合 (图 2a).

综上, 根据 $\mathrm{T} 1$ 点湖水温度垂直剖面, 纳木错东部浅湖盆从 5 月中旬湖冰融化开始, 上、下层湖水发生完 全混合. 其后, 水温一直上升, 温跃层逐渐出现, 并不断发展. 到 8、9 月份, 湖水开始维持稳定分层状态. 这个 过程中, 温跃层深度一直增加. 直到 11 月份, 温跃层消失, 整个湖水剖面再次混合.

\subsection{T2 点垂直剖面水温季节变化}

$\mathrm{T} 2$ 点 5 月份湖水水温在 $2 \sim 4{ }^{\circ} \mathrm{C}$ 范围内, 上、下层水温差异小, 基本保持不变, 以春季混合为特征. 混合 现象可能一直持续到 6 月中旬. 2011 年 6 月 13 日, 上、下层湖水水温仍在 $3.3 \sim 5.6^{\circ} \mathrm{C}$ 之间 (图 $2 \mathrm{~d}$ ).

7 月份, 湖水分层现象逐渐出现. 2013 年 7 月 4 日, 垂直剖面显示上部 $30 \mathrm{~m}$ 的水温随深度平缓地变化, 从 $10.8^{\circ} \mathrm{C}$ 降到 $4^{\circ} \mathrm{C}$. 而下部 $60 \mathrm{~m}$ 的水温却比较均一, 在 $3.4 \sim 4.0^{\circ} \mathrm{C}$ 之间. 混合均匀的湖上层和水温剧烈变 化的温跃层都没有出现 (图 2f).

7 月中旬和 8 月份, 典型的湖水分层现象开始出现, 混合较好的湖上层形成, 温跃层中水温梯度也变大. 2012 年 7 月 17 日, 湖上层分布在上部 $17 \mathrm{~m}$ 处, 水温为 $9.0 \sim 9.7^{\circ} \mathrm{C}$. 温跃层中, 水温从上部 $9^{\circ} \mathrm{C}$ 下降到 $30 \mathrm{~m}$ 的 $4.8^{\circ} \mathrm{C}$, 水温梯度平均值为 $0.32^{\circ} \mathrm{C} / \mathrm{m}$. 湖下层的水温则维持在 $3.6 \sim 4.8^{\circ} \mathrm{C}$ 之间 (图 $2 \mathrm{e}$ ).

$\mathrm{T} 2$ 点处湖水从 8 月中旬开始进人稳定分层阶段. 2013 年 8 月 14 日, 湖上层厚 $12 \mathrm{~m}$, 整个湖上层的水温 在 $11.6^{\circ} \mathrm{C}$ 左右, 反映出湖上层混合程度很高. 温跃层从 $12 \mathrm{~m}$ 左右开始, 直到 $42 \mathrm{~m}$ 结束. 其顶部水温在 $11^{\circ} \mathrm{C}$ 左右, 底部水温为 $4^{\circ} \mathrm{C}$. 湖下层水温在 $3.45 \sim 4.00^{\circ} \mathrm{C}$ 之间. 这种分层现象一直持续到 11 月份, 并且温跃层的 深度逐渐增加 (图 2f). 2013 年 9 月 8 日湖上层厚 $22 \mathrm{~m}$, 其平均水温为 $11.6^{\circ} \mathrm{C}$. 温跃层从 $22 \mathrm{~m}$ 左右开始, 到 $44 \mathrm{~m}$ 附近结束 (图 2f). 2011 年 10 月 29 日,表层水温约为 $7.4^{\circ} \mathrm{C}$, 比 $8 、 9$ 月份湖水表层水温低 $3 \sim 4^{\circ} \mathrm{C}$. 但湖 上层厚 $52 \mathrm{~m}$, 且混合均匀, 其顶部和下部水温差异不超过 $0.2^{\circ} \mathrm{C}$ (图 $2 \mathrm{~d}$ ).

11 月, $\mathrm{T} 2$ 点上、下层湖水翻转, 再次混合. 2012 年 11 月 26 日水温垂直剖面显示, 上、下层水温只有微小 变化, 其表层水温为 $4.15^{\circ} \mathrm{C}$, 底层水温为 $3.95^{\circ} \mathrm{C}$, 表明整个湖水剖面都发生混合, 且混合均匀 (图 $2 \mathrm{e}$ ).

综上, 纳木错湖泊中部较深湖盆从 5 月中旬湖面解冻开始, 湖水发生混合, 一直持续到 7 月初. 此后, 进 人夏半年湖水分层期. 湖水稳定分层从 8 月份开始. 11 月初, 上、下层湖水翻转, 进人秋季混合期, 直到 2 月 份湖面封冻.

\section{4 分析与讨论}

\section{1 纳木错湖水混合类型}

同气温一样, 很多湖泊水温有明显季节变化. 相应地, 分层现象也呈现出不同的季节格局. 因此, 很多湖 泊分类方案都是基于湖泊水温与分层、混合模式提出的 ${ }^{[14]}$. 以 $\mathrm{T} 1$ 点和 $\mathrm{T} 2$ 点为代表的纳木错水温垂直剖面 显示, 纳木错在春季解冻之后, 湖水进人混合期, 然后持续升温后, 湖水发生分层. $8 、 9$ 月份, 湖水分层继续发 展, 温跃层深度不断增加, 伴随湖上层的加厚和湖下层的减薄, 直至湖下层消失. 11 月, T1 点和 T2 点相继发 生秋季翻转,整个湖水剖面混合, 上、下层水温基本一致. 混合状态持续到湖面封冻.

因此, 根据 Lewis 在修正前人工作基础上提出的湖泊分类方案 ${ }^{[29]}$, 纳木错混合模式符合冬季封冻, 夏季 稳定分层, 春、秋季混合的特征, 应为双季对流混合型湖泊. 同时, $\mathrm{T} 1$ 、 $\mathrm{T} 2$ 点湖水在春、秋季完全混合, 纳木错 也是一个完全混合湖泊.

\section{2 东部、中部湖盆能量循环差异}

尽管 T1 和 T2 点有相同的混合模式, 但也存在着差异. 首先, 在春季湖水升温阶段, T1 点比 T2 点湖水 升温快. 在此基础上, $\mathrm{T} 1$ 点湖水在 6 月初至中旬开始出现明显的温跃层, $\mathrm{T} 2$ 点在 7 月初至中旬才开始出 现, $\mathrm{T} 1$ 点温跃层比 $\mathrm{T} 2$ 点提前大致 1 个月发生(图 3a). 8 月份, 湖水进人稳定分层状态以后, $\mathrm{T} 1$ 和 $\mathrm{T} 2$ 点的 水温分布曲线大致相同, 顶部湖水水温都在 $11.6^{\circ} \mathrm{C}$ 左右, 且温跃层深度都在不断增加, 直到湖下层消失 (图 3b、c). 其次, 湖水分层时, $\mathrm{T} 1$ 点和 $\mathrm{T} 2$ 点顶部水温变化趋势与气温变化趋势相似, 但其底部水温变化 则不同. $\mathrm{T} 1$ 点底部水温随温跃层加深而增加. 而 $\mathrm{T} 2$ 点底部湖水在整个分层期间, 水温都在 $3.4 \sim 3.6^{\circ} \mathrm{C}$ 之 间, 体现出 $\mathrm{T} 2$ 点底部湖水在夏季与外界的能量交换较为微弱 (图 4). 再次, $\mathrm{T} 1$ 点秋季翻转时间比 $\mathrm{T} 2$ 点提 前. 11 月份, $\mathrm{T} 1$ 点秋季翻转已经开始, 水温约 $8^{\circ} \mathrm{C}$, 而 $\mathrm{T} 2$ 点仍然处于分层状态, 湖上层水温在 $7 \sim 8^{\circ} \mathrm{C}$ 之间. 

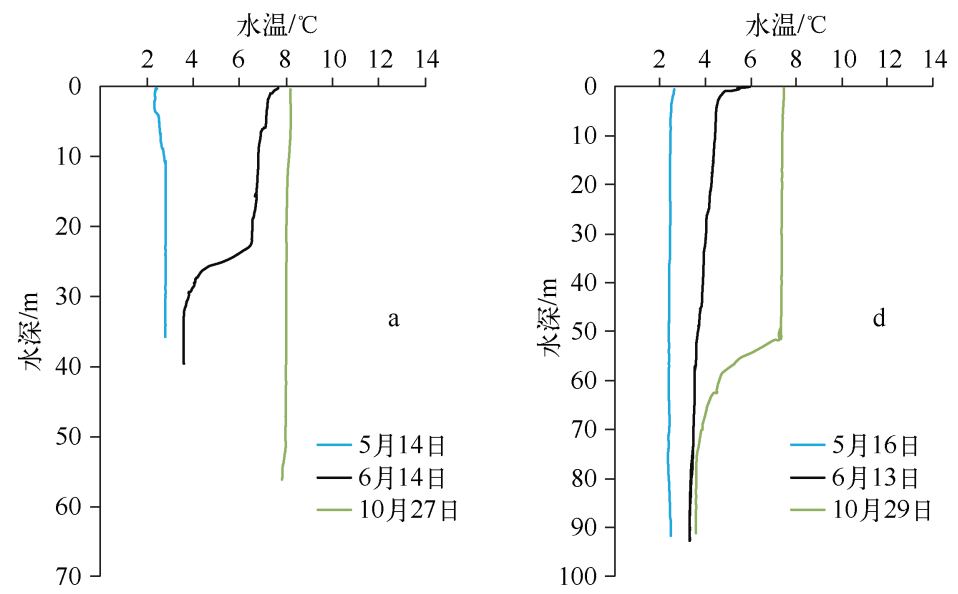

水温 $/{ }^{\circ} \mathrm{C}$

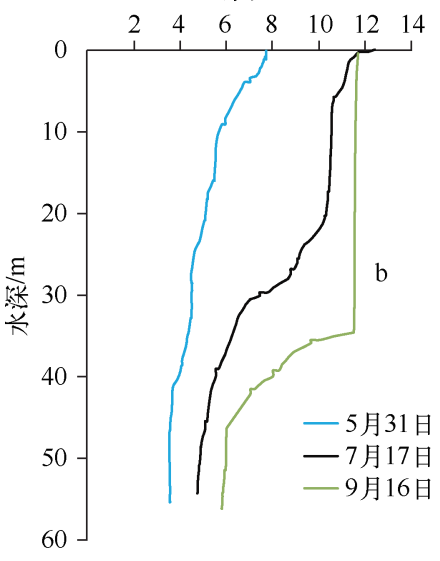

水温 $/{ }^{\circ} \mathrm{C}$
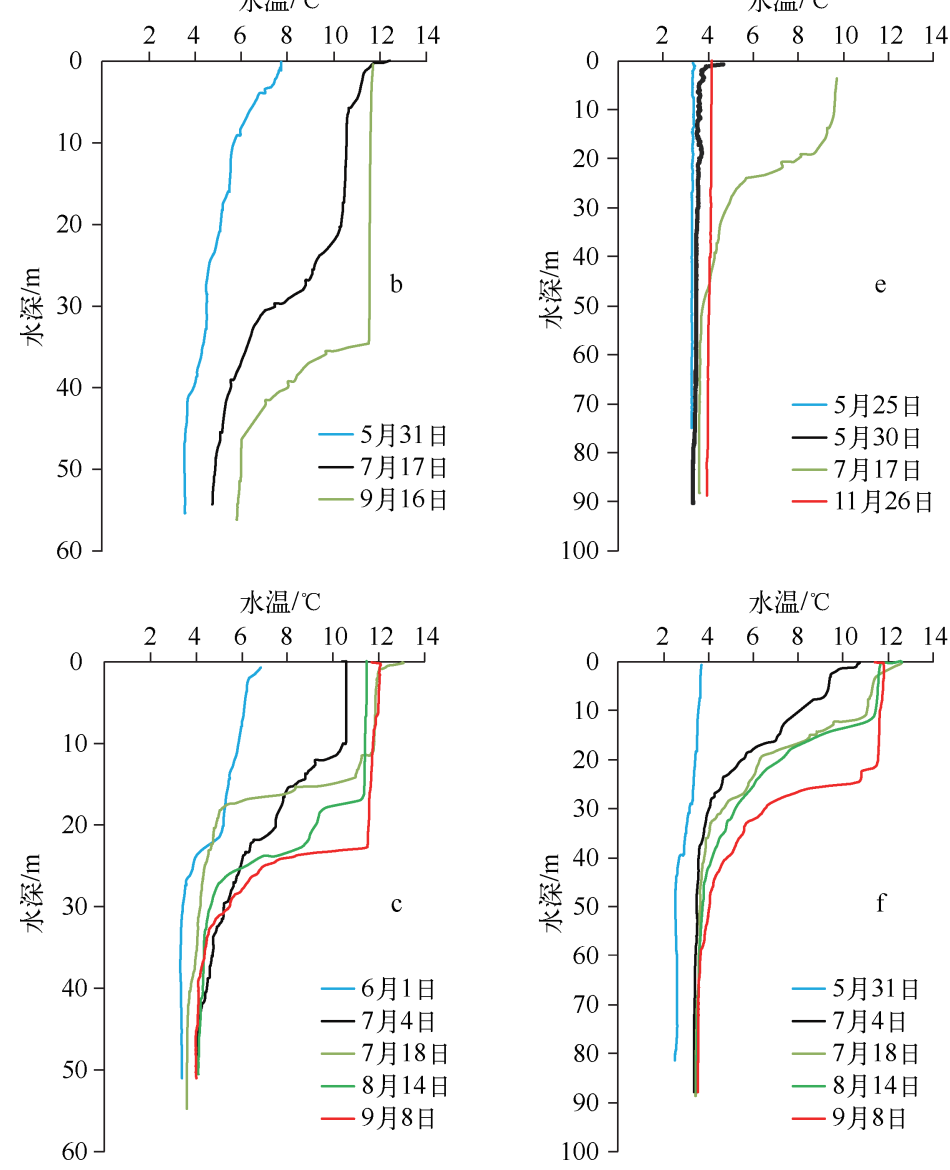

图 2 2011－2013 年纳木错 $\mathrm{T} 1$ 和 $\mathrm{T} 2$ 点水温变化 ( $\mathrm{a} \sim \mathrm{c}: \mathrm{T} 1$ 点; $\mathrm{d} \sim \mathrm{f}$ : T2 点)

Fig. 2 Variations of water temperature at T1 and T2 sites in Nam Co during 2011-2013 


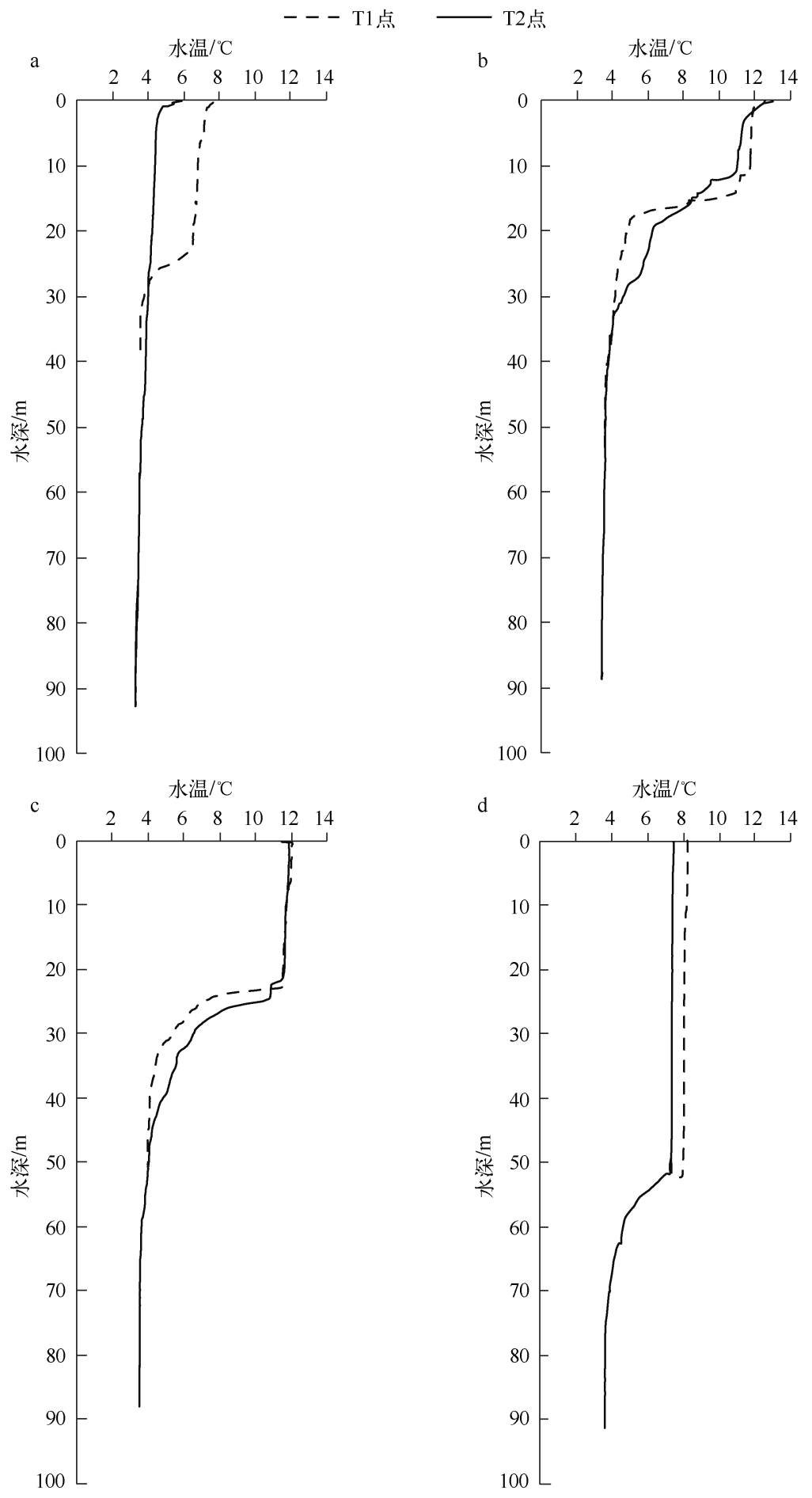

图 3 纳木错 $\mathrm{T} 1$ 与 $\mathrm{T} 2$ 点同时期水温对比 $(\mathrm{a}: 2011$ 年 6 月 $13-14$ 日; $\mathrm{b}$ :2013 年 7 月 18 日; $: 2013$ 年 9 月 8 日; $d: 2011$ 年 10 月 27-29日)

Fig. 3 Comparison of water temperature variations in the same periods at $\mathrm{T} 1$ and $\mathrm{T} 2$ sites in Nam Co 
此时, $\mathrm{T} 2$ 点湖上层的厚度与 $\mathrm{T} 1$ 点相当, 可见二 者的混合作用相似,但是 $\mathrm{T} 2$ 点深度更大,所以整 个剖面的湖水翻转需要更长时间 (图 3d). 同时 根据已有观测数据推测, $\mathrm{T} 1$ 点湖水剖面完全翻 转时的水温可能比 $\mathrm{T} 2$ 点高 $4^{\circ} \mathrm{C}$ 左右 (图 4). 综上 所述, 以 $\mathrm{T} 1$ 和 $\mathrm{T} 2$ 点为代表的纳木错东部、中部 两个湖盆由于湖盆形状和水深分布差异, 其能量 循环也有各自的特征.

\section{5 结论}

利用纳木错东部、中部 2 个湖盆的实地观测 资料,对纳木错水温季节变化和热力学分层特征 展开分析. 结果显示纳木错为典型双季对流、完 全混合型湖泊. 同时, 东部、中部湖盆水深分布差 异导致 2 个湖盆出现各自的能量循环特征.

在高原湖泊研究中, 湖泊混合类型研究还是 薄弱环节. 而湖泊水体混合对于湖泊生态、沉积 物形成都有重要影响. 高原分布有众多咸水湖,

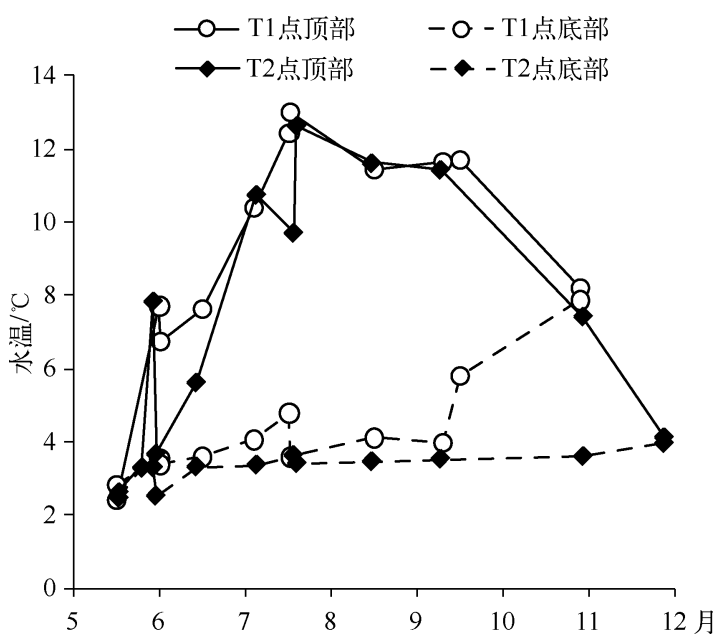

图 4 纳木错 $\mathrm{T} 1$ 和 $\mathrm{T} 2$ 点垂直剖面顶部、 底部水温季节变化

Fig. 4 Seasonal distribution of surface and bottom water temperature at $\mathrm{T} 1$ and $\mathrm{T} 2$ sites in Nam Co 已报道的达则错、兹格塘错均为半混合型湖泊 ${ }^{[6,30]}$, 巨大的盐度梯度是维持其混合特征的重要因素. 班公错、 纳木错为淡水、微咸水湖泊,盐度小, 不存在巨大盐度梯度, 因而湖水在春、秋季发生翻转 ${ }^{[30]}$. 双季对流混合 型的湖泊在翻转时,上、下层湖水能发生物质、能量交换,这对于湖泊底部生物生存有重要意义. 然而, 半混 合型湖泊下部永滞层与上层湖水之间的物质、能量交换相对微弱,封闭的还原环境利于有机质保存,也影响 生物的垂直分布 ${ }^{[14,31]}$. 这些研究的开展, 为认识高原淡水、咸水湖泊的湖沼学特征提供参考,也表明高原湖 泊不同于其他地区湖泊,有独特的物理化学过程. 因此,在开展湖泊沉积研究与湖泊生态研究过程中, 需要 进一步加强对湖泊现代过程的研究.

致谢: 中国地质大学 (武汉) 林晓博士、德国耶拿大学 Dr. Gerhard Daut、中国科学院青藏高原研究所张继峰、 杨瑞敏、胡星、陈锋等参与了野外工作,纳木错监测工作得到了中国科学院纳木错多圈层综合观测研究站的 支持和协助,在此一并表示感谢.

\section{6 参考文献}

[ 1 ] Qiu J. China: The third pole. Nature, 2008, 454:393-396.

[ 2 ] 王苏民, 窦鸿身. 中国湖泊志. 北京:科学出版社, 1998:7.

[3] 王君波,朱立平. 青藏高原湖泊沉积与环境演变研究: 现状与展望. 地理科学进展,2005,24(5):1-12.

[4] 沈 吉. 湖泊沉积研究的历史进展与展望. 湖泊科学,2009,21(3):307-313.

[ 5 ] 关志华,陈传友, 区裕雄等. 西藏河流与湖泊. 北京:科学出版社, 1984:1-238.

[ 6 ] 李万春,李世杰,尹 宇等. 青藏高原腹地半混合型湖泊的发现及其意义. 中国科学: D 辑: 地球科学, 2001,31 (增 刊) :269-272.

[ 7 ] Mitamura O, Seike Y, Kondo K et al. First investigation of ultraoligotrophic alpine Lake Puma Yumco in the pre-Himalaya, China. Limnology, 2003, 4: 167-175

[ 8 ] Murakami T, Terai H, Yoshiyama Y et al. The second investigation of Lake Puma Yum Co located in the Southern Tibetan Plateau, China. Limnology, 2007, 8: 331-335.

[ 9 ] 王君波,朱立平, Gerhard Daut 等. 西藏纳木错水深分布及现代湖沼学特征初步分析. 湖泊科学, 2009,21(1): $128-134$

[10 ] Zhu LP, Ju JT, Wang JB et al. Further discussion about the features of Lake Puma Yum Co, South Tibet, China. Limnology, 2010, 11 : 281-287. 
[11] 王君波,彭 萍,马庆峰等. 西藏当惹雍错和扎日南木错现代湖泊基本特征. 湖泊科学,2010,22(4):630-634.

[12］康世昌,杨永平,朱立平等. 青藏高原纳木错流域现代环境过程及其变化. 北京:气象出版社,2011:1-418.

[13] 王君波, 彭 萍, 马庆峰等. 西藏玛旁雍错和拉昂错水深、水质特征及现代沉积速率. 湖泊科学, 2013,25 (4): 609-616.

[14］Jacob Kalff 著. 古滨河, 刘正文, 李宽意等译. 湖沼学一内陆水生生态系统. 北京: 高等教育出版社, 2011:36-180.

[15] 李小平,程 䂀,陈小华等.湖泊学. 北京:科学出版社,2013:72-73.

[16] Goldman CR, Horne AJ. Limnology. New York: McGraw-Hill, 1983 : 39.

[17] 金章东, 张飞, 李福春等. 青海湖湖水性质、颗粒物沉积通量季节和年际变化一一来自沉积物捕获器的研究. 地 球环境学报,2013,4(3):1306-1313.

[18］李 燕,金章东. 青海湖介形虫壳体丰度与氧碳同位素的季节和年际变化及其控制因素一一来自沉积物捕获器的 研究. 地球环境学报,2013,4(3):1328-1337.

[19] Dibike Y, Prowse T, Saloranta T et al. Response of Northern Hemisphere lake-ice cover and lake-water thermal structure patterns to a changing climate. Hydrological Processes, 2011, 25(19) : 2942-2953.

[20] Taner MU, Carleton JN, Wellman M. Integrated model projections of climate change impacts on a North American lake. Ecological Modelling, 2011, 222 (18) : 3380-3393.

[21] Lee HW, Kim EJ, Park SS et al. Effects of climate change on the thermal structure of lakes in the Asian Monsoon Area. Climatic Change, 2012, 112(3/4) : 859-880.

[22] Gebre S, Boissy T, Alfredsen K. Sensitivity to climate change of the thermal structure and ice cover regime of three hydropower reservoirs. Journal of Hydrology, 2014, 510 : 208-227.

[23] Keil A, Berking J, Mügler I et al. Hydrological and geomorphological basin and catchment characteristics of Lake Nam Co, South-Central Tibet. Quaternary International, 2010, 218 : 118-130.

[24] 吴䎦红,朱立平, 叶庆华等. 纳木错流域近 30 年来湖泊一冰川变化对气候的响应. 地理学报, 2007,62(3):301-311.

[25] 陈 锋,康世昌,张拥军等. 纳木错流域冰川和湖泊变化对气候变化的响应. 山地学报,2009,27(6):641-647.

[26] 游庆龙,康世昌,李潮流等. 青藏高原纳木错气象要素变化特征.气象,2007,33(3):54-60.

[27] Zhou SQ, Kang SC, Chen F et al. Water balance observations reveal significant subsurface water seepage from Lake Nam Co, south-central Tibetan Plateau. Journal of Hydrology, 2013, 491 : 89-99.

[28] 曲 斌, 康世昌, 陈 锋等. 2006-2011 年西藏纳木错湖冰状况及其影响因素分析. 气候变化研究进展,2012,8 (5) $: 327-333$

[29] Lewis WM Jr. A revised classification of lakes based on mixing. Canadian Journal of Fisheries and Aquatic Sciences, $1983, \mathbf{4 0}:$ : 1779-1787.

[30］王明达,侯居峙,类延斌. 青藏高原不同类型湖泊温度季节变化及其分类. 科学通报,2014,59:4847-4855.

[31] Boehrer B, Schultze M. Stratification of lakes. Reviews of Geophysics, 2008, 46(2) : RG2005. 